\title{
Framing Metagovernance in the Context of Developing Democracies: An Institutionalist Viewpoint
}

\author{
Athaulla A Rasheed (PhD.) \\ HDR Candidate, School of Government and International Relations, \\ Griffith University \\ 170 Kessels Road, Nathan, QLD 4111 \\ E-mail: athaulla.rasheed@griffithuni.edu.au
}

Received: June 1, 2020 Accepted: June 28, 2020 Online published: July 27, 2020

doi:10.5296/jpag.v10i3.17105 URL: https://doi.org/10.5296/jpag.v10i3.17105

\begin{abstract}
Metagovernance has traditionally been evolving as an effective mode of governance in developed democracies for states or governments to legitimately steer and coordinate stakeholder governance across jurisdictions. This article extends this work to understand the application of metagovernance in the context of developing democracies. Using an institutionalist viewpoint, the article explores the conceptual and empirical bases of metagovernance, drawing from the political science and political economy literature on developing economies to explain how political institutions can shape the state capacity to metagovern socio-economic activities in developing democracies. This article finds that the state capacity to metagovern can be challenged by weak democratic political practices.
\end{abstract}

Keywords: metagovernance, political economy, democracies, developing economies, historical institutionalism.

\section{Introduction}

Both empirical and conceptual foundations of metagovernance have traditionally been rooted in developed democracies including the Organization for Economic Cooperation and Development (OECD) economies. This system of governance has been evolving as an effective way for the state or government to direct and manage socio-economic activities in dealing with multiple wicked problems and crises across jurisdictions (Evans, 2007; Larsson, 2017) and apply central steering to achieve public policy objectives (Gjaltema, Biesbroek \& Termeer, 2019; Meuleman, 2019; Torfing \& Triantafillou, 2013; Umukoro, 2014; Werlin, 2009). Not just the big bailout of 2008 (see Collins, 2015) but also the way current governments across the globe have been required to step in to curb both the health and 
socio-economic effects of the recent Covid-19 pandemic indicates the type of central role the state plays in metagovernance (see Mazzucato, 2020). Metagovernance provides public policy management tools to address governance failures between the state and non-state market actors (Gjaltema et al., 2019; Larsson, 2017). It recognizes the state capacity to centrally steer governance of multiple policy strategies of community stakeholders by coordinating their governance arrangements particularly without scaring off market innovators and non-governmental actors across state, regional and local levels (Jossep, 2002; Kooiman, 2003; Torfing \& Triantafillou, 2013). Moreover, experiences from Australia, Denmark and most European Union (EU) economies demonstrate that state capacity to metagovern is predominantly shaped by democratic institutionalism - public accountability, transparency, legitimacy and rule of law (Bell \& Hindmoor, 2009; Damgaard \& Torfing, 2010). This means that metagovernance entails neo-liberal democratic institutional functions including central steering of devolved governance, effective policy process, resource management, democratic best practice, and accountability and legitimacy of political process (Bailey \& Wood, 2017; Bell \& Hindmoor, 2009; Considine, 2003; Koch \& Buser, 2006; Jessop, 1997, p. 575; Lance, Georgiadou \& Bregt, 2009, p. 252; Meuleman, 2019; Sørensen, 2006). These institutional functions enable the state to responsibly and legitimately engage with and centrally coordinate public policy objectives between policy makers and society by limiting traditional hierarchical state practices such as command and control politics (Jessop, 2002; Kooiman, 2003; Sørensen \& Torfing, 2009; Torfing \& Triantafillou, 2013). In this way, metagovernance is portrayed as a state-led institutional process to legitimately govern societal activity (Bell \& Hindmoor, 2009; Jessop, 1997, p. 575; Lance et al., 2009, p. 252; Sørensen \& Torfing, 2009; Sørensen, 2006).

This article seeks to understand the application of metagovernance in the context of developing democracies. Using an institutionalist viewpoint, it explores conceptual and empirical bases of metagovernance, and draws on the political science and political economy literature on developing economies to explain how political institutions can affect the state capacity to metagovern socio-economic activities in developing countries. This informs how the type of political institutions in these economies can shape their state or government practices. This article argues that the state capacity to metagovern in developing democracies can be lost due to weak democratic practices leading to persistent failure to govern economic performance responsibly and legitimately.

This article uses a qualitative research method and draws from historical literature on political economy and development studies to investigate how and why institutional properties of developing democracies have challenged socio-economic governance. Developing democracies have weak formal and informal institutions and culturally transmitted political practices that do not adhere to the rule of law and democratic best practices (North, 1990, 2005; Pierre \& Peters, 2005; Rasheed, 2006, 2013a; Ratnapala, 2003). Such institutions can encourage private interests of the ruling elite, rent-seeking practices and cliental relationships in the policy process (The Economist, 2011; Fukuyama, 2012; Hindmoor, 1999; Laffont \& Tirole, 1991; Tullock, Seldon \& Brady, 2002). For example, despite abundant resources and new liberal institutional foundations, developing democracies 
in Ghana, Mexico, Argentina (Auty, 2004a) and the Maldives (Rasheed, 2015) have shown persistent failures of the state to govern balanced development. East and Southeast Asian states in the 1990s had adopted predatory rent-seeking, luring the economies into economic crisis (Azam, Bates \& Biais, 2009, p. 4; Onis, 1991). They all indicated a disconnect between democratic institutionalism and state-led governance. On the other hand, neo-liberal democratic state practices helped a resource-abundant Malaysian government to also promote export-oriented manufacturing in the late1960s and avoid a staple trap (Abidin, 2004; Amin, Yusof \& Haneef, 2006; Koen, Asada \& Nixon, 2017). These historical experiences further inform the function of institutions at both formal and informal levels (North, 1990). Short and long-term development success or failures have been impacted by their capacity to adopt good governance in the context of democratic best practices. Although metagovernance literature does not cover developing democracies, this review finds scope to extent metagovernance studies to understand its application in the latter's context.

The article proceeds by providing an evaluation of available metagovernance literature to explain how democratic institutionalism supports state capacity to metagovern. This evaluation is followed by a review of political science and political economy literature to understand how political institutions in developing democracies affect their capacity to govern development. This review further develops a conceptual building block to further understand the political practices of the state in developing democracies that affect state capacity to metagovern. In conclusion, this article finds an inevitable relationship between state capacity to metagovern and the political system, and this relationship can explain the politico-institutional challenges in the implementation of metagovernance.

\section{Metagovernance and State Capacity to Metagovern}

There have been significant changes to the modes of governance in contemporary societies (Bell \& Hindmoor, 2009; Sørensen, 2006, p. 99). Multiple forms of collaborative and network governance have evolved in a time where the sovereign role of the state to micromanage societal activity has diminished (Jessop, 1997, p. 573; Qvist, 2017; Sørensen, 2006). The traditional central role of the state has been hollowing out (Damgaard \& Torfing, 2010 , p. 258). Self-regulated policy networks are the new governance and managers of societies. The art of self-regulation and self-governance are a commonplace practice both in public-private investments and business management. The horizontal distribution of governance arrangements is spreading across different sectors. This merging of public and private spheres has been leading to blurring of the boundaries between state and society (Bell $\&$ Hindmoor, 2009, p. 3-4). These society-centred and network-based policies and market systems have been gaining considerable attention in both scholarly debate and policy discourses up to date (Bell \& Hindmoor, 2009).

Scholarly debate and policy discourse have not completely abandoned state-centric policy engagements. Policy leadership and key accountability of the state in public policy management are essentially required more often than expected. This central function of the state became attractive when governments had to step in to bail out big businesses in the aftermath of the 2008 global financial crisis (Bell \& Hindmoor, 2015). The US government 
was blamed for not taking the necessary measures to "stop the housing bubble in the early 2000s" (Kotz, 2009, p. 313) and prevent a global economic recession in the late 2000s (Makin, 2009). The magnitude of the current Covid-19 crisis has required governments across the globe to step in. State-led governance and market stimulation have been effective in balancing social and economic policy outcomes in order to address a very complex market economy situation (Mazzucato, 2020). Such events have demanded a greater role from the state in directing and managing socio-economic activities at global, regional and local levels. In times of crises, governments have been held responsible for market and socio-economic systems failures.

European developed economies like Denmark and Sweden have shown practices of good governance which put the state at the forefront of governance structures - not as a pre-historic monolithic type governance, but as a governance based on plurality and complexity (Larsson, 2017; Sørensen, 2006, p. 100). Modern governance literature identifies this mode of state-led governance as metagovernance. This idea has furthermore invited discussions about the state capacity to centrally coordinate collaboration between multiple societal issue-based activities to support balanced development ${ }^{1}$ (Bell \& Hindmoor, 2009, p. 55-58; Meuleman, 2019; Sørensen, 2006, p. 103). It bridges constitutional requirements of the states and public-private interests (Bell and Hindmoor, 2009, p. 63; Jessop, 1997, p. 575; Lance et al., 2009, p. 252; Pierre \& Peters, 2000, p. 1; Sørensen, 2006, p. 102).

Metagovernance informs a political process where the state becomes a democratic and resourceful actor in governing society. State-led metagovernance ensures central steering that does not jeopardize the integrity of self-regulated markets. Damgaard and Torfing (2010) demonstrate that the government of Denmark successfully used the Local Employment Councils (LECs) as an instrument of metagovernance to centrally manage and monitor the "performance of local job centres" through "multi-level" governance arrangements without undermining the original objectives of self-regulated local networks by creating "regulated self-regulations" (pp. 249-251). Bell and Hindmoor (2009, p. 47) explain that Australia's Job Network provided a means for the government to centrally steer and horizontally manage the programs of non-state actors. This type of hands-off and hands-on action enables devolved central steering through delegating resources and authority to local public authorities to legitimately coordinate and manage policy implementation across state and local stakeholders (Bailey \& Wood, 2017; Considine, 2003). LECs in Demark have demonstrated the effect of this bounded autonomy on other governance arrangements. LECs function under legislation but have the freedom to "define their own rules of the game, set their own agenda, make their own political priorities, draw up their own plan for using their centrally allocated funds, and use the LECs as a platform for developing new ideas and initiatives" (Damgaard \& Torfing, 2010 , p. 253). LECs attained the capacity to steer, as they operated under the national policy framework. This effect of bounded autonomy allowed the state to meet its policy objectives while also enabling LECs to perform according to their local policy platforms. This type of devolved steering enables the state to implement its public policy across local sectors.

\footnotetext{
${ }^{1}$ Balanced development adheres to the idea that "development can only be achieved if growth is accompanied by an improvement in the quality of life, which includes a reduction in social problems" (Amin et al., 2006, p. 151).
} 
Metagovernance also provides the state with the administrative and financial resources required to adopt and implement policy. Bell and Hindmoor (2009, p. 49) explain that a large administration and bureaucracy, a reliable fiscal resource base, regulatory bodies and legislative laws can provide the state with a large resource base to direct and manage other governance arrangements such as LECs in governing local job centres. The state can delegate a finance or economics ministry that has the capacity to distribute resources and monitor monetary policy, and the authority to distribute resources to coordinate policy between public service authorities and society. Lance et al. (2009) demonstrate that the central budgetary agencies (CBAs) in the United States (US) and Canada assume the function of controlling resources for their governments. By assuming this responsibility, CBAs can drive the functions and activities of policy authorities in achieving their sectoral policies in alignment with the political and policy objectives of the state. This function puts CBAs "in a unique and pivotal position to assume the role of metagovernor and facilitator of joined up policy making" (Lance et al., 2009, p. 254). In the case of the US and Canada, CBAs have assumed a legitimate authority through the democratic process that their state and society follow. This makes CBA oversight a legitimate, centralized function of the state that can provide resources for metagovernance (Bell \& Hindmoor, 2009, p. 49).

CBAs furthermore make the point that metagovernance is efficient in modern liberal democracies (Damgaard \& Torfing, 2010, p. 258; Koch \& Buser, 2006; Kooiman \& Jentoft, 2009; Lance et al., 2009, p. 249; Sørensen, 2006). In studying the practices of metagovernance, Sørensen (2006) explains that "metagovernance produces a different form of governance than in the case with sovereign forms of rule, and that metagovernance is in many cases the only applicable form of governance in modern Western democracies" (p. 102). Democratic institutional characteristics bring legitimacy to the central role of government especially when steering market forces and non-government actors. Coordinating collaboration between policy authorities and stakeholders can create room for the state to interfere with the natural process of decision making by involving private political interests and cliental behavior (Gjaltema et al., 2019). However, the democratic legislative process can further check and balance policy making procedures as well as the political bias of the state (Bell \& Hindmoor, 2009). The legislative checks and balances can simultaneously provide incentives for and apply constitutional constraints on predatory activities of the state (Fischer, 2006; Bellamy \& Castiglione, 1997, p. 609). Therefore, by adopting a democratic process, metagovernance ensures the democratic participation of stakeholders in a devolved state-led decision-making process.

The democratic process also ensures accountability from the political authority and for policy inputs and outputs (Mulgan, 2006, p. 49). This ensures that other stakeholders in the governance arrangements are also held accountable by the state. Bell and Hindmoor (2009) demonstrate that, in 2001, the Australasian Correctional Management (ACM) was criticized and held responsible by both the opposition parties and media for the poor conditions it had put in place for prisoners, which eventually led to a number of unpopular events including a series of riots and breakouts within the facility (Bell \& Hindmoor, 2009, p. 53). In this type of scenario, the state is held responsible for failing to monitor misconduct in the public 
administration system. In the same case, the Department of Immigration and Multicultural Affairs (DIMA) was also warned by the Australian National Audit Office for not having put in place adequate monitoring mechanisms (Bell \& Hindmoor, 2009, p. 53). The state accountability system enabled respective government authorities to hold responsible public service authorities accountable for misconduct and make changes. The provision of accountability in the democratic process furthermore ensured legitimacy of the state in its conduct of public services through the metagovernance arrangement.

Bell and Hindmoor (2009), consistent with Fritz Scharpf (1997, 1999), characterize this democratic provision of accountability and criterion of fairness in public service delivery as the input-oriented legitimacy. The democratic process enables publicly elected policy makers to make a legitimate policy input in coordinating collaboration between policy authorities and stakeholders. This input also accompanies a democratic process involving checks and balances on the state to maintain legitimacy in decision-making processes. In the ACM and DIMA case, the state came under pressure from the public where the democratic process furthermore required the relevant policy authorities to review and regulate the existing prison policies and system. As Bell and Hindmoor (2009, p. 54) argue, "if governments effectively steer governance arrangements, ensure effectiveness, and provide necessary resources, the legitimacy of the output is [also] enhanced". When legitimacy depends on the nature of policy output, the state is required to make the necessary changes to policy output to achieve outcomes collectively desired by the state and society. This state capacity to steer, provide resources and function within the democracy process determines the use and implementation of metagovernance.

From the literature reviewed it can be concluded that the democratic process is an essential function of metagovernance (Gjaltema et al., 2019). In this respect, metagovernance literature also discusses potential challenges to the implementation of democratic governance when fair participation of stakeholders is not included in state-led governance (Bristow, Entwistle \& Martin, 2008; Evans, 2007; Gjaltema et al., 2019; Qvist, 2017; Sørensen, 2006). This, however, does not reject the central role the state has in metagoverning society. Such observations recognize the importance of democratic institutionalism in ensuring the effectiveness of metagovernance. This observation can help drive scholarly and policy debate to extend its application and implementation to developing democracies in order to explore the implications of lack of democratic institutionalism. Although broader metagovernance literature does not discuss the context of developing democracies, the political science literature largely covers studies on state-led governance and development in developing economies. The following section discusses how state capacity to govern economic performance is affected by weak democratic processes and practices in such economies.

\section{Political Economy and Governance in Developing Democracies}

Lack of democracy is constitutive of lack of legitimacy. It can allow political leaders to manipulate policy apparatuses for political and private advantages and rent-seeking activities (Auty, 1993; Fischer, 2006). This does not suggest that developed countries have failproof political-economic institutions to combat misgovernance. This claim follows the premise that 
legitimate political institutions and practices in developed democracies have been a pre-condition for metagovernance success stories. Similarly, the application of metagovernance in developing democracies is explained in the context of their state capacity to govern socio-economic activities.

Most developing democracies in Africa, Latin America, and Asia acquire institutional properties that can enable authoritarian policy makers to manipulate policies and legislation for their own advantage (Auty, 1993; Bell \& Hindmoor, 2009; Fischer, 2006; Skach, 2005, p. 355). Ideas and processes of Westernization, liberal democracy and free market systems have made an unavoidable impact on non-Western developing economies (Bell \& Hindmoor, 2009, p. 65; Wade, 1990; Wang, 2008). Such economies have abandoned many of their traditional command and control governance practices (Bell \& Hindmoor, 2009, p. 75). Absolute authority is not the only form of governance adopted in these societies (Bell \& Hindmoor, 2009, p. 63; Gill, 2003; Mann, 1988; Considine, 2003). However, this does not mean that they can adopt metagovernance functions. One must understand the nature of their political economy to ascertain whether they are capable to do so. Political economy literature explains that limited democratic institutionalism can enable the state to abuse hierarchical authority. State-society interactions are also likely to be lured into regulatory capture ${ }^{2}$ (Laffont \& Tirole, 1991; Stigler, 1971) as in Ghana during the 1960s and 1970s (see Osei, 2004, p. 165). The state can govern the economy, but not necessarily coordinate collaborative decision making across stakeholders. Rather, cliental relations with the privileged can produce unbalanced socio-economic outcomes.

The literature on abundant resources and resource curse theory inform an explanatory framework about such economies. They explain how resource-rich developing democracies have produced slow growth and persistent inequality due to poor planning caused by policy misconduct (Auty, 1993). Resource-abundant developing economies in Africa, Latin America, and Asia have shown slower growth trajectories than economies of East Asia with low or non-existent resources (Auty, 1993; Karl, 1997; Murshed, 2004, p. 113). Over the past few decades, political scientists and economists including Alan Gelb (Center for Global Development, 2012) and Auty (1993), have studied such economies using time-series empirical data to understand the correlation between development, abundant resources and political economy. Developing democracies with abundant resources have tended to grow two or three times slower than economies without. Auty (2004b) shows that "per capita incomes of the resource-poor countries grew at rates two and three times faster than those of the resource-abundant countries" (pp. 3-4). Similar studies have revealed that there is a curse of underdevelopment behind rich resource endowments (Auty, 1993, pp. 249-252; Bulte, Damania \& Deacon, 2005, p. 1030; Ross, 1999). According to Murshed (2004), "resource booms retard the growth of the economy via the crowding out of production in the traded sectors" (p. 115). When this happens, the human capital and productivity improvement in traded sectors (manufacturing or agriculture) is reduced (Sachs \& Warner, 2001), as widely explained using the concept of Dutch disease (Auty, 1993; Auty, 2004b; Sachs \& Warner,

\footnotetext{
${ }^{2}$ Regulatory capture involves government making policies or legislation favorable to special interest private groups to establish or maintain their market monopolies (Dal Bó, 2006).
} 
2001, p. 835). In the long run, underdevelopment is caused by the diminishing productive capacity of the workforce in the tradable sector as human capital development in this sector becomes less relevant. According to Auty (2001), this effect of abundant resources slows industrialization, which in turn impedes urbanization "so that the favourable phase of the dependency/worker cycle is delayed, and the accumulation of produced and human capital is slower" (p. 844). This process also postpones the "labour market turning point" causing "surplus rural labour to raise both income inequality and social tension" (p. 844).

What happens is that a high concentration of resources in a single industry attracts government interest to that industry (IDS, 2007). A resource-abundant industry can generate a large amount of revenue for the government. This will draw government's attention away from other areas of the economy including accountability to its constituencies. Selective relationships with the resource-abundant industry further weakens its legitimacy. The reliance on the huge revenue base reduces the incentives for government to invest in and develop other economic sectors. This was seen in the post-independent states of Africa, Latin America, and Asia.

Resource curse literature finds that rent-seeking is a manifestation of government failure ${ }^{3}$ in resource-abundant countries (Auty, 1993, p. 115; Murshed, 2004). In studying the development trajectory and political economy of resource-abundant countries, Osei (2004) demonstrates that the sub-Saharan African state, Ghana, a small country with cocoa as a key abundant resource, fell into a "staple trap" or experienced an economic collapse due to the "weak" economic policies adopted by its post-independent authoritarian government from the 1960 s to the 1980s. Ghana achieved independence in 1957, inheriting (quasi-)democratic institutions from its pre-independence British system. A democratically appointed prime minister headed the post-independent state. The "absence of balance of payment constraints, a sound budgetary situation and a well-functioning public administration" provided Ghana with substantially better economic conditions to start with compared to other countries of the region (Osei, 2004, p. 165). However, the economic policies of Prime Minister Nkrumah, which his successors continued, failed to address developmental problems effectively due to their temptations towards rent-seeking activities, engendered by the immense windfall of abundant resources.

Nkrumah based his economic policies of the 1960s on "pan-African" ideologies, which promoted "bid push" policies to accelerate industrialization at the expense of other producing industries (Osei, 2004). This approach created a less open economy by imposing foreign exchange restrictions and attempted an import substitution strategy by imposing import quotas and specific import restriction licenses. Overall, Nkrumah took control of the cocoa industry and its revenue as he saw fit, using resource rents to pay for political commitments. His Seven-Year Development Plan (1962-1970) further expanded the government and its administrative functions. The plan was financed from domestic resources, including the revenue base acquired from "implicit taxation of cocoa exports" (Osei, 2004, p. 167).

\footnotetext{
3 The same literature suggests that this government failure lies within the government's incapacity to manage national resources to achieve broader development of the economy, due to weak political systems built on a political-institutional framework undermining effective governance mechanisms.
} 
Basically, he created a "vampire state" that generated rent-like resources and adopted policies that were unproductive and less growth friendly, which subsequently led to a growth collapse towards the 1980s. The fixed rent enabled the state to generate a huge revenue base from a single industry and gave little policy attention to other areas of the economy, causing a subsequent growth failure.

Mexico and Argentina also experienced similar development failures around the same period. They are resource-abundant economies, among other Latin American economies, which collapsed due to the "weak" policies of their governments (Auty, 2004a). Like the "vampire state" in Ghana, the governments of these countries were both led by self-interested leaders who were prone to rent-seeking and corruption (Auty, 2004b). They acquired large economies with characteristics of self-sufficiency and higher intensity for economic diversification. Like Ghana, they also experienced relatively good economic conditions in the initial phase of the post-independence governance process. However, both Mexico and Argentina accommodated a factional predatory political state that sought huge rents from the resource industries, and where economic policies redistributed national resources and revenue towards favorable members of an oligarchy (Auty, 2004a, p. 212). The state seldom paid attention to economic policies that could have promoted sustainability of the broader economy. In Mexico, the state failed to manage its revenue from oil to strengthen the domestic economy and support local industrialization. The revenue was used to meet political costs and budget deficits (Auty, 2004a). Auty (2004b) concluded that "in predatory and factional states [such as Ghana, Mexico and Argentina], the natural resource rents are captured and redistributed by non-transparent means to favoured constituencies within protected industry, the public sector, the military or regional or ethnic groups" (p. 318). When this happens, the state subsequently falls into a form of willing capture, ${ }^{4}$ involved in political rent-seeking from the rich industry (Auty, 1993, p. 32; Murshed, 2004, p. 115; Hindmoor, 1999, p. 435; Meier \& Rauch, 2005). Rent-seeking activities diminish the responsibility of and need for the state to achieve national and local objectives (Auty, 1993; Mehlum, Moene \& Torvik, 2006, p. 3; Ngo, 2008).

Sachs and Warner (2001) argue that resource abundance can lead to "poorer governments" and hence "lower growth" (p. 835). However, this is not an automatic process. Rather, it is an outcome of state capacity to manipulate economic governance for private benefits. A rent-seeking relationship has the tendency to make government invest resources in an effort to achieve monopolistic rents under favorable legislative conditions for private gains, but at the expense of the overall welfare of society (Hindmoor, 1999, p. 435; Hindmoor, 2006a, p. 80; Tullock, 1988; Tullock et al., 2002, pp. 43-51). Good governance literature explains that the economic outcomes of rent-seeking can cause more harm to the wider society than if they had taken place in a different institutional context that does not allow abusive government activity (Fischer, 2006; Hindmoor, 1999). From a public choice and rational choice standpoint, governments promote rent-seeking because it is a source of political power and

\footnotetext{
${ }^{4}$ A few big businesses influence the government policy agenda. Such businesses have a higher tendency to influence government regulatory frameworks when they know their per-capita stake is high. They would want to manipulate economic regulations to maximize private benefits.
} 
capital (Hindmoor, 2006a, 2006b). Rent-seeking can be caused by a mere intervention of the government in economic activity in the absence of democratic rules to guarantee socio-economic rights of people (Fischer, 2006; Tullock et al., 2002). In the absence of democratic rules self-interested politicians are more likely to develop policies for their own advantage (Fischer, 2006; Hindmoor, 2006b, p. 180). Such constitutional rules can come in the form of legislative checks and balances to prevent bad government (North, 1990, pp. 59-60). During the oil boom (1980-1993), Indonesia, Malaysia (Abidin, 2004), and Norway (in theory a developed democracy), used "the gains from the oil booms to constitute industrial base by investing in the industrial sector instead of increasing public and private consumption" (Baland \& Francois, 2000, p. 539). What enabled such policies would be their democratic constitutional rules (Hindmoor, 2006b, pp. 174-178; North, 1990, pp. 33-35), which protected and preserved property rights of their societies. Countries such as Trinidad and Nigeria that lacked rules to protect property rights adopted predatory policies to use their oil gains to finance increased consumption (Baland \& Francois, 2000, p. 539; Fischer, 2006). In these latter circumstances, the state failed to effectively govern all levels of the economy. Weak institutional conditions have been the leading cause of slow growth, economic downturn and political instability in such economies of developing or quasi-democratic countries (Auty, 1993; Hopkin, 2006; Ross, 1999, p. 297; Sachs \& Warner, 2001).

In retrospect, the presence of abundant resources does not always lead to governance failure or bad government. Political regimes have played significant roles in determining positive developmental outcomes. Malaysia, for example, is classified as a resource-abundant developing democracy (among others such as Botswana, Chile, and Thailand) that has escaped the resource curse by systematically diversifying its economy from "slow-growth commodities to high-growth commodities and then into competitive manufacturing" (Abidin, 2004, p. 147). The democratic constitutional rules inherited from its pre-independence British system set the guiding principles for an efficient market system. The post-independence constitution created a federal system that became the cornerstone of democratic governance in Malaysia. Unlike Ghana or Mexico, the state adopted policies that promoted economic liberalism and balanced development. Abidin (2004) explains:

Malaysia did not dissipate the rents generated by the dynamic resource sector in expanding a slow-maturing manufacturing sector at the expense of incentives in the primary sector. Instead, the rents were channelled into strengthening output in the primary sector and into the accumulation of produced and human capital. Therefore, the decision to promote export-oriented manufacturing from the late-1960s helped Malaysia to avoid the staple trap and achieve competitive industrialization. (p. 158)

Its economic success story resonates in present studies including OCED papers (Koen, et al., 2017). But what if there were no abundant resources? Does this mean that institutions are not necessary?

Some resource-poor countries have performed remarkably well. East and Southeast Asian economies of the 1990s are some examples of such economies. During their economic booms, these governments played a leading role in managing national resources and economic 
activities to achieve productive outcomes. This explains that natural wealth does not automatically create predatory political systems. Onis (1991, pp. 117-118) demonstrates that Korea and Taiwan's development trajectories were shaped by political institutions and extensive industrial and infrastructural foundations that were historically bestowed on them by the Japanese. Initially, these countries did not experience political predation as in Ghana, Mexico, and Argentina. These East and Southeast Asian economies also experienced a growth collapse following their growth boom (Acemoglu, 2005, p. 1201). However, such states, in the long run, have failed to effectively manage their booming economies because their financial systems were too vulnerable to address changing market conditions (Wade, 1998, p. 1538). Their state institutions eventually failed to support metagovernance, shape legitimate state-society interactions and prevent predatory state behavior (Wade, 1990; Wang, 2008). Onis (1991, p. 123) explains that "the state elite [can] extensively regulate economic and political activity but at the same time [can also] take decisions without routine, institutionalized negotiations with groups in civil society". In this context, there is also a risk for Malaysia of being captured by a resources trap unless it continues to realize the role institutions play in guiding democratic governance. The following section draws on institutionalist literature to explain how formal and informal institutions can determine the lack of state capacity to metagovern due to persistent failure of the state to adopt democratic practices.

\section{Loss of State Capacity to Metagovern}

Loss of state capacity to metagovern has also been an area of concern for developing democracies. It has been argued that developing democracies lack the capacity to metagovern due to lack of democratic practices in political and policy processes (Rasheed, 2013b; 2015). Institutionalists explain this in terms of how institutions and constitutional rules affect developmental patterns (Hall \& Taylor, 1996; Rasheed, 2006; Ratnapala, 2003; Streeck \& Thelen, 2005). North (1990, p. 4) explains that institutions "are the frameworks within which human interaction takes place". Institutions are a key determinant of politics, policy making and governance both in developed and developing economies (Bell, 2011; North, 1990, 2005; Streeck \& Thelen, 2005). Democratic rules and practices play a key role in determining the legitimacy of policy processes in democratic political systems and can explain the persistent failure to metagovern in developing democracies. Neither the weak nor strong states are themselves drivers of policy processes, but the surrounding institutions are. Acemoglu (2005, p. 1203) promotes a “consensually strong-state" equilibrium (p. 1203). Using North's (1981, p. 1223) institutional theory, Acemoglu (2005, p. 1223) explains that "the delivery of public goods comes with significant rents for the ruler; the incentive compatibility constraint necessitates that, despite its political weakness, the ruler receives sufficient rents so that he[/she] is not tempted to use tax revenue for his[/her] own benefit". Furthermore, an "equilibrium can emerge when citizens accept high taxes ... [if] there is a credible promise that a sufficient fraction of these will be invested in public goods" (Acemoglu, 2005, p. 1224).

This behavior of the state, with respect to non-state actors in producing efficient developmental outcomes, is demonstrated by OECD countries. OECD states with fairly weak 
political governments ${ }^{5}$ constrained by constitutionally imposed checks and balances portray highly successful developmental projections (Acemoglu, 2005, p. 25). The main implication of this argument is that these "consensually strong states" have democratic constitutional rules that ensure the effectiveness of the policy process. This is done through continuous negotiation and collaboration between policy authorities and non-state actors to reach a "pareto optimality" - all actors involved benefit (at least to some extent) from policy outcomes. This consensually strong state is an outcome of democratic constitutional rules. Lack of democratic rules and subsequent failure to sustain developmental progress in developing democracies is an indication of lack of metagovernance. Rasheed (2015, 2013a, 2013b) explains how historical institutions enabled authoritarian political practices and rent-seeking policies in tourism development in the Maldives during the 1970s and 2000s. The state failed to metagovern tourism to achieve balanced socio-economic development despite the large revenue generated for the state. The lack of democratic process created a disconnection between the state and broader societal activities. What diminished the state capacity to metagovern was the type of political institutions inherited from past authoritarian practices.

In studying the economic histories of Western societies and their relations with non-Western societies, such as Latin American states, North (1990, pp. 101-103) found that strong liberal institutions can reduce the costs of transactions in socio-economic activities and create incentives for progressive state-society performance. To understand why a political economy accommodates weak or strong institutions, we need to investigate its origins. North (1990) found that the success of US revolutions that led to "the Revolutionary War, the Declaration of Independence, the Articles of Confederation, the Northwest Ordinance, and the Constitution" was affected by its historical institutional legacies transferred from the British liberal institutionalism (North, 1990, p.102). He also found that the institutional legacies of the Spanish Indies, which promoted centralized bureaucratic controls inherited by the Latin American economies, did not support the US-inspired "federal schemes and efforts of decentralization" in those economies (North, 1990, p. 103). The underlying argument is that pre-existing constitutional rules influence the success and failures of present and future governance arrangements.

In Asia, Africa, or Latin America, governance of socio-economic activity is guided by weak or developing democratic institutions. However, their capacity to metagovern will depend on their ability to adopt and continue democratic practices. In the Maldives, the post-independence political system inherited many historical monarchical political practices that adhered to authoritarian ruling. Despite the resource-rich tourism generated since the 1970s, the state has failed to metagovern the industry to achieve balanced development (Rasheed, 2015, 2013b). In comparison to the governance modes of the United Kingdom (UK), the Netherlands, Germany and the European Commission, Meuleman (2010) argues that the governance modes of one nation cannot be simply transferred as best practice to another without adaptation. This capacity to adapt depends on both formal and informal

\footnotetext{
${ }^{5}$ Here, "weak" government is referred to as a government under certain check and balance mechanisms constraining the exercise of unlimited or undue authority over the economy.
} 
political institutions in place. Governments can renegotiate their social contracts with non-state actors and implement new democratic practices. In order to implement new policies, governments must adopt new laws and regulations to guide that implementation process. These changes to legislation or formal rules will in turn change the nature of relations between the government and non-state actors (North, 1990). However, these changes may not necessarily change the traditional practices and ideologies of those occupying actors unless the new formal rules can modify the original desire-structure of those actors through better incentivized structures (Bell \& Hindmoor, 2009; North, 1990; Streeck \& Thelen, 2005; Thelen, 1999; van der Heijden, 2010).

North (1990, p. 6) explains that "institutions typically change incrementally rather than in discontinuous fashion" because the informal rules embedded in the political-economic system are hard to change, as they are accustomed elements of society. Historical institutionalists discuss a "sticky" effect of institutions on surrounding environments by setting a distinct path for any interplay between occupying agencies. They advocate that institutions tend to create "interpretive" actors with "bounded discretion" who can make strategic choices in order to adapt to changing socio-economic conditions, like varying market prices and competition (Bell, 2011, pp. 10,19). This institution-induced "adaptive efficiency" of the state will determine the nature of changes and the effectiveness of their outcome (North, 1990, pp. 80-81; 2005). According to North (1990), adaptive efficiency can be explained in terms of a society's willingness to make changes to its social, economic and political structures. This willingness depends on the type of institutions governing that political society. If such institutions create adequate incentives and constraints for society to develop, then that society is considered adaptively efficient. If that outcome does not meet the desired end of the occupiers, it implies a weakness of the original institutions in setting effective apparatuses to govern their interplay and reaching long-term socio-economic solutions. Institutions may change, but they do not necessarily change efficiently. The weakness of the original path reduces the adaptive efficiency of society to make institutional change (North, 1990; Ratnapala, 2003).

Bell (2011), in line with other social science and political science theories (Archer, 1995; Bell \& Hindmoor, 2009; North, 1990), created a methodological framework to explain this institutional effect of path dependency in the context of historical institutionalism. Bell (2011, p. 2) suggests that both the government and industry, within an institutional structure, have "bounded discretion" and independent "interpretive" capacities to adapt to new socio-economic conditions by formulating better governance strategies. Bounded discretion allows actors to make informed decisions on their surrounding environments. It enables actors to adapt and make political and economic changes, but only within the boundaries of existing institutional frameworks. This asserts that actors can make their own changes; but their actions are still essentially influenced by the pre-existing institutions. These institutional paths influence governance arrangements and their developmental outcomes. Peters (1999), consistently with Bell (2011) and North (1990), defines path dependency as "the policy choices made when an institution is being formed, or when a policy is initiated, [that] will have a continuing and largely determinant influence over the policy far into the future" (p. 
63). Thelen (1999) confirms that "even when policy makers set out to redesign institutions, they are constrained in what they can conceive of by these embedded, cultural constraints" (p. 386).

In analysing the independence of the Reserve Bank of Australia (RBA) in the early 1990s, for Bell $(2004,2011)$ it was clear that the government could not effectively metagovern the monetary system by failing to strategically steer the RBA's activity with respect to the national economic system. This led to a policy-induced economic recession in the 1990s. This failure was a result of structural problems caused by weak pre-existing legislation. The RBA was unable to pursue its policy independence because government leaders had strong political control over its functions. The recession changed the initial situation, made it costlier for politicians to pursue their RBA functions and provoked a policy shift under existing legislation. Their job was made easier because "the legislation [that] already existed made it possible for the authorities to implement institutional change on an informal basis and tacitly give the RBA its head during this period"' (Bell, 2011, p. 19).

In this state-institution interplay, one can observe a persistent failure of state capacity to metagovern in developing democracies. For example, Ghana failed to establish an efficient economic policy because its constitutional rules were too undemocratic. Instead, it experienced political revolutions and military coups between the 1960s and 1980s (Osei, 2004, pp. 167-169). The same can be applied to Latin American or Asian economies including the case of the Maldives with developing democratic systems. The continuity of authoritarian political practices can reduce state capacity to metagovern in these systems. Malaysia can be a test case to explain the continuity of state capacity to centrally coordinate good economic performance and assess if metagovernance is the cause of its success story. Studies have indicated the role the institutional foundations have played to curb corruption and misgovernance in Malaysia's development planning (Bakar, Barizah, Saleh \& Mohamad, 2011; Koen et al., 2017, p. 36). Likewise, the Maldives has undergone modern democratic reforms and thus is a good case to assess metagovernance challenges caused by historical institutions. Moreover in Malaysia, as in the Maldives, institutional paths with authoritarian practices from pre-independence political traditions can still drive predatory politics, and hence the ability to metagovern socio-economic activities can be affected by the state capacity to adhere to democratic practices. It is the state capacity to coordinate market force collaboration and societal activities within democratic boundaries that can determine metagovernance in these developing economies.

\section{Conclusion}

This article is based on the institutionalist perspective of conceptual and empirical foundations of metagovernance and on an approach that frames metagovernance in the context of developing democracies. The crucial point is whether or not the state has the capacity to direct, manage and coordinate collaboration between policy authorities and societal stakeholders. In the context of metagovernance functions, this article has explained that, historically, developing democracies have not attained sufficient democratic practices to support central steering of their economy. State-led governance has not worked when the 
political system in place has not provided checks and balances to prevent private political interests and relationships characterized by clientelism between the state and society. Rather, states often fall into a form of willing capture.

The research culminating from this article, however, highlights that Malaysia's post-independent democratic practices once enabled liberal market practices that supported economic progress. The state coordinated the industrialization process in a sustainable way. This highlights the benefits of an institutionalist approach to understand the application of metagovernance in developing democracies. Metagovernance has not been studied in the context of developing democracies except for the case of Maldives where it was observed that post-independence political institutional practices have challenged the state capacity to metagovern tourism development. Southeast Asian states in the1990s showed the economic potential for development. However, the impact of weak rules led to the failure of the political system to metagovern economic performance. In Malaysia, however, despite the quasi-democratic institutions, good governance practices of the government have shown the potential for metagovernance, and possible growth of future studies focusing on developing democracies.

\section{References}

Abidin, M. Z. (2004). Competitive industrialisation with natural resource abundance: Malaysia. In R. M. Auty (Ed.), Resource abundance and economic development (pp. 147-164). New York: Oxford University Press.

Acemoglu, D. (2005). Politics and economics in weak and strong states. Journal of Monetary Economics, 52(7), 1199-1226. https://doi.org/10.1016/j.jmoneco.2005.05.001

Amin, R. M., Yusof, S. A., \& Haneef, M. A. M. (2006). Values, social problems and balanced development in Malaysia. The Journal of Socio-Economics, 35(1), 151-163. https://doi.org/10.1016/j.socec.2005.12.009

Archer, M. (1995). Realist social theory: The morphogenetic approach. Cambridge: Cambridge University Press.

Auty, R. M. (1993). Sustaining development in mineral economies: The resource curse thesis. London: Routledge.

Auty, R. M. (2001). The political economy of resource-driven growth. European Economic Review, 45(4-6), 839-846. https://doi.org/10.1016/S0014-2921(01)00126-X

Auty, R. M. (2004a). Large resource-abundant countries squander their size advantage: Mexico and Argentina. In R. M. Auty (Ed.), Resource abundance and economic development (pp. 208-222). New York: Oxford University Press.

Auty, R. M. (2004b). Resource abundance and economic development. New York: Oxford University Press.

Azam, J. P., Bates, R., \& Biais, B. (2009). Political predation and economic development. Economics and Politics, 21(2), 255-277. https://doi.org/10.1111/j.1468-0343.2009.00345.x 


\section{Macrothink}

Journal of Public Administration and Governance

ISSN 2161-7104

2020, Vol. 10, No. 3

Bailey, D., \& Wood, M. (2017). The metagovernance of English devolution. Local Government Studies, 43(6), 966-991. https://doi.org/10.1080/03003930.2017.1359165

Bakar, A., Barizah, N., Saleh, Z., \& Mohamad, M. H. S. (2011). Enhancing Malaysian public sector transparency and accountability: Lessons and issues. European Journal of Economics, Finance and Administrative Sciences, 31, 133-145.

Baland, J-M., \& Francois, P. (2000). Rent-seeking and resource booms. Journal of Development Economics, 61(2), 527-542. https://doi.org/10.1016/S0304-3878(00)00067-5

Bell, S. (2004). Australia's money mandarins: The Reserve Bank and the politics of money. Melbourne: Cambridge University Press.

Bell, S. (2011). Do we really need "constructivist institutionalism" to explain institutional change? British Journal of Political Science, 41(4), 1-24.

Bell, S., \& Hindmoor, A. (2009). Rethinking governance: The centrality of the state in modern society. Port Melbourne, Victoria: Cambridge University Press.

Bell, S., \& Hindmoor, A. (2015). Masters of the universe, slaves of the market. London: Harvard University Press.

Bellamy, R., \& Castiglione, D. (1997). Constitutionalism and democracy — political theory and the American Constitution. British Journal of Political Science, 27(4), 595-618. https://www.jstor.org/stable/194230

Bristow, G. I., Entwistle, T. W., \& Martin, S. J. (2008). New spaces for inclusion? Lessons from the "three-thirds" partnerships in Wales. International Journal of Urban and Regional Research, 32(4), 903-921. https://doi.org/10.1111/j.1468-2427.2008.00822.x

Bulte, E. H., Damania, R., \& Deacon, R. T. (2005). Resource intensity, institutions, and development. World Development, $\quad 33(7), \quad$ 1029-1044. https://doi.org/10.1016/j.worlddev.2005.04.004

Center for Global Development. (2012). Alan Gelb. [Online] Available: http://www.cgdev.org/content/expert/detail/1423702/ (June 17, 2020).

Collins, M. (2015, July 14). The big bank bailout. Forbes. [Online] Available: https://www.forbes.com/sites/mikecollins/2015/07/14/the-big-bank-bailout/\#7eefdf962d83 (June 17, 2020).

Considine, M. (2003). Governance and competition: The role of non-profit organisations in the delivery of public services. Australian Journal of Political Science, 38(1), 63-77. https://doi.org/10.1080/1036114032000056251

Dal Bó, E. (2006). Regulatory capture: A review. Oxford Review of Economic Policy, 22(2), 203-225. https://doi.org/10.1093/oxrep/grj013 


\section{Macrothink}

Journal of Public Administration and Governance ISSN 2161-7104 2020, Vol. 10, No. 3

Damgaard, B., \& Torfing, J. (2010). Network governance of active employment policy: The Danish experience. Journal of European Social Policy 20(3), 248-262. https://doi.org/10.1177/0958928710364435

Evans, B. (2007). The Politics of partnership: Urban regeneration in New East Manchester. Public Policy and Administration, 201-215. https://doi.org/10.1177/0952076707075896.

Fischer, P. V. (2006). Rent-seeking, institutions and reforms in Africa: Theory and empirical evidence for Tanzania. New York: Springer.

Fukuyama, F. (2012). China and East Asian democracy: The patterns of history. Journal of Democracy, 23(1), 14-26.

Gill, G. (2003). The nature and development of the modern state. Basingstoke: Palgrave.

Gjaltema, J., Biesbroek, R., \& Termeer, K. (2019). From government to governance ... to meta-governance: A systematic literature review. Public Management Review, 1-21. https://doi.org/10.1080/14719037.2019.1648697

Hall, P. A., \& Taylor, R. C. R. (1996). Political science and the three New Institutionalisms. Political Studies, 44(5), 936-957. https://doi.org/10.1111/j.1467-9248.1996.tb00343.x

Hindmoor, A. (1999). Rent seeking evaluated. The Journal of Political Philosophy, 7(4), 434-452. https://doi.org/10.1111/1467-9760.00085

Hindmoor, A. (2006a). Public choice. In C. Hay, M. Lister, \& D. Marsh (Eds.), The state: Theories and issues (pp. 79-97). New York: Palgrave MacMillan.

Hindmoor, A. (2006b). Rational choice. New York: Palgrave MacMillan.

Hopkin, J. (2006, August 31). Conceptualising political clientelism: Political exchange and democratic theory. Paper presented at the APSA annual meeting, "Concept analysis: Unpacking clientelism, governance and neoliberalism", London. [Online] Available: http://personal.lse.ac.uk/HOPKIN/apsahopkin2006.pdf (June 17, 2020).

IDS (Institute of Development Studies). (2007). How does taxation affect the quality of governance? Policy Briefing, issue 34, March. [Online] Available: https://opendocs.ids.ac.uk/opendocs/bitstream/handle/20.500.12413/12795/IDS_PB_How_D oes.pdf? sequence=1\&isAllowed=y $($ June 17, 2020)

Jessop, B. (1997). Capitalism and its future: Remarks on regulation, government and governance. Review of International Political Economy, 4(3), 561-581. https://doi.org/10.1080/096922997347751

Jessop, B. (2002). The future of the capitalist state. Cambridge: Polity Press.

Karl, T. L. (1997). The paradox of plenty: Oil booms and petro-states. California: University of California Press. 
Koch, C., \& Buser, M. (2006). Emerging meta-governance as an institutional framework for public private partnership network in Denmark. Science Direct, 24, 548-556.

Koen, V., Asada, H., \& Nixon, S. (2017). Malaysia's economic success stories and challenges. Organisation for Economic Co-operation and Development (OECD). [Online] Available: https://www.oecd.org/eco/Malaysia-s-economic-success-story-and-challenges.pdf (June 17, 2020).

Kooiman, J. (2003). Governing as governance. London: Sage.

Kooiman, J., \& Jentoft, S. (2009). Meta-governance: Values, norms and principles, and the making of hard choices. Public Administration, 87(4), 818-836. https://doi.org/10.1111/j.1467-9299.2009.01780.x

Kotz, D. M. (2009). The financial and economic crisis of 2008: A systemic crisis of neoliberal capitalism. Review of Radical Political Economics, 41(3), 305-317.

Laffont, J., \& Tirole, J. (1991). The politics of government decision-making: A theory of regulatory capture. Quarterly Journal of Economics, 106(4), 1089-1127. https://doi.org/10.2307/2937958

Lance, K. T., Georgiadou, Y., \& Bregt, A. K. (2009). Cross-agency coordination in the shadow of hierarchy: "Joining up" government geospatial information systems. International Journal of Geographical Information Science, 23(2), 249-269. https://doi.org/10.1080/13658810801909615

Larsson, O. (2017). Meta-governance and collaborative crisis management-competing rationalities in the management of the Swedish security communications system. Risk, Hazards \& Crisis in Public Policy, 8(4), 312-334. https://doi.org/10.1002/rhc3.12120.

Makin, J. H. (2009, July 1). A government failure, not a market failure. The Wall Street Journal. [Online] Available: http://online.wsj.com/article/SB124631486277570583.html (June 17, 2020).

Mann, M. (1988). States, war, and capitalism. Oxford: Blackwell.

Mazzucato, M. (2020, March 19). The Covid-19 crisis is a chance to do capitalism differently. The Guardian. [Online] Available: https://www.theguardian.com/commentisfree/2020/mar/18/the-covid-19-crisis-is-a-chance-to -do-capitalism-differently (June 17, 2020).

Mehlum, H., Moene, K., \& Torvik, R. (2006). Institutions and the resource curse. The Economic Journal, 116(508), 1-20. https://doi.org/10.1111/j.1468-0297.2006.01045.x

Meier, G. M., \& Rauch, J. E. (2005). Leading issues in economic development. New York: Oxford University Press.

Meuleman, L. (2010). The cultural dimension of metagovernance: Why governance doctrines may fail. Public Organization Review, 10(1), 49-70. 
Meuleman, L. (2019). Metagovernance for sustainability: A framework for implementing the sustainable development goals. Public Sector Economics, 43(1), 109-113.

Mulgan, R. (2006). Government accountability for outsourced services. Australian Journal of Public Administration, 65(2), 48-58. https://doi.org/10.1111/j.1467-8500.2006.00481.x

Murshed, M. S. (2004). Short-run models of contrasting natural resource endowments. In R. M. Auty (Ed.), Resource abundance and economic development (pp. 113-125). New York: Oxford University Press.

Ngo, T. W. (2008). Rent-seeking and economic governance in the structural nexus of corruption in China. Crime, Law and Social Change, 49(1), 27-44.

North, D. C. (1981). Structure and change in economic history. New York: W. W. Norton and Company.

North, D. C. (1990). Institutions, institutional change and economic performance. Cambridge: Cambridge University Press.

North, D. C. (2005). Understanding the process of economic change. Princeton: Princeton University Press.

Onis, Z. (1991). The logic of the developmental state. Comparative Politics, 24(1), 109-126. https://www.jstor.org/stable/422204

Osei, R. (2004). A growth collapse with diffuse resources: Ghana. In R. M. Auty (Ed.), Resource abundance and economic development (pp. 165-178). New York: Oxford University Press.

Peters, B. G. (1999). Institutional theory in political science: The new institutionalism. New York: Pinter.

Pierre, J., \& Peters, B. G. (2000). Governance, politics and the state: Political analysis. New York: Palgrave Macmillan.

Pierre, J., \& Peters, B. G. (2005). Governing complex societies: Trajectories and scenarios. New York: Palgrave MacMillan.

Qvist, M. (2017). Meta-governance and network formation in collaborative spaces of uncertainty: The case of Swedish refugee integration policy. Public Administration, 95(2), 498-511. https://doi.org/10.1111/padm.12310

Rasheed, A. A. (2006). The relationship between economic transition and constitutional government: The experience of the Republic of Maldives. Lawasia Journal, 2006, 227-245.

Rasheed, A. A. (2013a). An institutionalist approach to understand the recent political change in the Maldives. LAWASIA Journal, 2012, 159-182.

Rasheed, A. A. (2013b). Tourism, economic development and governance in the Maldives: A historical institutional evaluation. $\mathrm{PhD}$ thesis, University of Queensland, Brisbane. 
Rasheed, A. A. (2015). Development, development policy and governance in the Maldives: A political economy perspective. Maldive National University Research Journal, 3(1), 29-51. http://saruna.mnu.edu.mv/jspui/handle/123456789/325

Ratnapala, S. (2003). Securing constitutional government: The perpetual challenge. Independent Review: A Journal of Political Economy, 8(1), 5-22. https://www.jstor.org/stable/24562593

Ross, M. L. (1999). The political economy of the resource curse. World Politics, 51(2), 297-322. https://www.jstor.org/stable/25054077

Sachs, J. D., \& Warner, A. M. (2001). Natural resources and economic development: The curse of natural resources. European Economic Review, 45(4-6), 827-838.

Scharpf, F. (1997). Games real actors play: Actor-centred institutionalism in policy research. Boulder, CO: Westview Press.

Scharpf, F. (1999). Governing in Europe: Effective and democratic? Oxford: Oxford University Press.

Skach, C. (2005). Constitutional origins of dictatorship and democracy. Constitutional Political Economy, 16(4), 347-368.

Sørensen, E. (2006). Metagovernance: The changing role of politicians in processes of democratic governance. The American Review of Public Administration, 36(1), 98-14. https://doi.org/10.1177/0275074005282584

Sørensen, E., \& Torfing, J. (2009). Making governance networks effective and democratic through metagovernance. Public Administration, 87(2), 234-258. https://doi.org/10.1111/j.1467-9299.2009.01753.x.

Stigler, G. (1971). The theory of economic regulation. Bell Journal of Economic and Management Science, 2(1), 3-21. https://www.jstor.org/stable/3003160

Streeck, W., \& Thelen, K. (2005). Beyond continuity: Institutional change in advanced political economies. New York: Oxford University Press.

The Economist. (2011). What China challenges: The case for democracy should be made on moral, rather than economic ground. [Online] Available: https://www.economist.com/democracy-in-america/2011/07/11/what-china-challenges (June $17,2020)$.

Thelen, K. (1999). Historical institutionalism in comparative politics. Annual Review of Political Science, 2, 369-404. https://doi.org/10.1146/annurev.polisci.2.1.369

Torfing, J., \& Triantafillou, P. (2013). Introduction to interative policy making, metagovernance and democracy. In J. Torfing, \& P. Triantafillou (Eds.), Interactive policy making, metagovernance and democracy (pp. 1-28). New York: ECPR Press. 


\section{Macrothink}

Journal of Public Administration and Governance ISSN 2161-7104 2020, Vol. 10, No. 3

Tullock, G. (1988). Rents and rent-seeking. In C. K. Rowley, R. D. Tollison, \& G. Tullock (Eds.), The political economy of rent-seeking (pp. 51-63). Boston: Kluwer Academic Publishers.

Tullock, G., Seldon, A., \& Brady, G. L. (2002). Government failure: A primer in public choice. Washington: Cato Institute.

Umukoro, N. (2014). Democracy and inequality in Nigeria. Journal of Developing Societies, 30(1), 1-24. https://doi.org/10.1177/0169796X13516340

van der Heijden, J. (2010). A short history of studying incremental institutional change: Does Explaining Institutional Change provide any new explanations? Regulation \& Governance, 4(2), 230-243. https://doi.org/10.1111/j.1748-5991.2010.01075.x

Wade, R. (1990). Governing the market: Economic theory and the role of government in East Asian industrialization. Princeton: Princeton University Press.

Wade, R. (1998). The Asian debt-and-development crisis of 1997? Causes and consequences. World Development, 26(8), 1535-1553. https://doi.org/10.1016/S0305-750X(98)00070-9

Wang, M. (2008). The political economy of East Asia: Striving for wealth and power. Washington: CQ Press.

Werlin, H. H. (2009). The case of democracy: Remaining questions. Journal of Developing Societies, 25(3), 339-370. https://doi.org/10.1177/0169796X0902500303

\section{Copyright Disclaimer}

Copyright for this article is retained by the author(s), with first publication rights granted to the journal.

This is an open-access article distributed under the terms and conditions of the Creative Commons Attribution license (http://creativecommons.org/licenses/by/4.0/). 